\title{
Postnatal Development of the Urine Cortisol/Creatinine Ratio in the Dog
}

\author{
K. VOSTATKOVÁ ${ }^{1,4}$, P. ŠTARHA ${ }^{2}$, P. KALÁB ${ }^{3}$, J. BLAHOVÁ $^{1}$, E. BARANYIOVÁ ${ }^{1}$ \\ ${ }^{1}$ Department of Veterinary Public Health and Toxicology, ${ }^{3}$ Department of Biophysics and Biochemistry, \\ Faculty of Veterinary Hygiene and Ecology, University of Veterinary and Pharmaceutical Sciences, \\ Brno, Czech Republic \\ ${ }^{2}$ Department of Computer Graphics and Geometry, Faculty of Mechanical Engineering, \\ Brno University of Technology, Czech Republic \\ 4) Veterinary Clinic Erika, Prague, Czech Republic \\ Received August 16, 2007 \\ Accepted April 14, 2008
}

\begin{abstract}
Vostatková K., P. Štarha, P. Kaláb, J. Blahová, E. Baranyiová: Postnatal Development of the Urine Cortisol/Creatinine Ratio in the Dog. Acta Vet. Brno 77, 2008: 509-513.

The objective of this experiment was to study the age changes of cortisol to creatinine ratio in urine of growing puppies between birth and the age of 8 weeks. Beagle puppies $(n=14)$ of three litters were used. The puppies of litters 1 and 2 were from a research breeding facility and litter 3 from a dog breeder. They were nursed by their dams and obtained extra puppy food from the $4^{\text {th }}$ week of age. The puppies were weighed weekly. Morning urine was sampled at the age of up to $48 \mathrm{~h}$, and 7, 14, 21, 24, 35, and 56 days. Urine cortisol was measured using the RIA method, and creatinine was determined using a diagnostic kit. The urine cortisol to creatinine ratio (UCCR) was calculated. The body mass of puppies increased more than ten times. The UCCR for litters 1 and 2 as against litter 3 showed no significant differences and therefore the results were pooled. Thus no effect of the rearing environment upon this indicator was found. The UCCR values in puppies aged up to $48 \mathrm{~h}$ was $44.32 \pm 30.47 \times 10^{-6}$. Its following changes (a decrease to $30.52 \pm 12.98 \times$ $10^{-6}$ on day 7 and oscillations around these values until day 49) as well as an increase on day 56 were not significant. Characteristic features of the UCCR in puppies were values surpassing those reported for healthy adult animals, and a great inter-individual variability, presumably reflecting the maturation processes such as rapidly increasing body mass and skeletal musculature mass, changes in nutrition, locomotory activity and maturation of their excretory system. The specific features of this period should be considered when evaluating the UCCR in puppies.
\end{abstract}

Age changes Beagle, growth, body mass, urine, cortisol, creatinine

Changes in cortisol secretion have repeatedly been measured as a response to various stressors in animals (e.g. Kojima et al. 1995, Boissy and Le Neindre 1997). Since blood collection itself is often stressful for animals, non-invasive sample collection methods have been developed and validated. They only minimally disturb the animals and enable to assess their cortisol concentrations in saliva and urine, and have also been used in dogs when studying their welfare issues or diagnosing diseases (Beerda et al. 1996, 1999ab; Beerda et al. 2000, Stolp et al. 1983).

When urine is used for analysis, quantitative measurement of its cortisol excretion can be determined for a $24 \mathrm{~h}$ urine collection period. However, an alternative to $24-\mathrm{h}$ collection is the determination of the urine cortisol to creatinine ratio (UCCR) in a random sample of urine since creatinine excretion is expected to be fairly constant during 24-h periods in healthy animals (Finco 1997). Thus the ratio of cortisol and creatinine in the urine can be used to account for the effect of urine concentration. A simple stress, such as a car ride or visit to a veterinarian may cause a mild increase in this ratio (van Vonderen et al. 1998; Ruotsalo and Tant 2004).

In adult undisturbed (non-stressed) Beagle dogs the UCCR values between $6.2 \pm 1.0 \times$ $10^{-6}$ and $17.8 \times 10^{-6}$ were found (e.g. Jones et al. 1990; Beerda et al. 1996; Stephen and Ledger 2006). Although various aspects of renal functions during postnatal development

Address for correspondence:

E. Baranyiová

Dept. of Veterinary Public Health and Toxicology, FVHE

University of veterinary and Pharmaceutical Sciences

Phone: + 420541562791

Palackého 1-3, 61242 Brno, Czech Republic 
of dogs were studied in some detail, such as body compartments and PAH clearance in neonatal puppies and regulation of their renal functions (Čapek and Heller 1961; Heller and Čapek 1965), we found no data on UUCR in puppies. It has been known that their nephrogenesis is incomplete at birth, and their glomerular filtration rate (GFR) increases between days 2 and 77 sevenfold (Horster and Valtin 1971, in Finco 1997). Lane et al. (2000) performed a quantitative urinalysis in Beagle puppies aged 9 to 27 weeks, and qualitative urinalysis in different breeds of puppies aged 0-8 weeks was presented by Faulks and Lane (2003); however, no UCCR was included in these studies. We therefore decided to study the development of cortisol/creatinine ratio in puppies aged 0 to 8 weeks after birth.

\section{Materials and Methods}

A total of fourteen newborn Beagle puppies of three litters were included in the study. Two litters $(n=8$, 3 males and 5 females) were sired by the same male, born and reared in a research facility and kept at room temperature of $26.5^{\circ} \mathrm{C}$ and relative humidity of $38 \%$, natural daylight. Beginning from week 4 , the puppies were offered additional puppy food. They were dewormed on day 1 (Probican, Medipharm), 26 (Drontal Junior Bayer, Germany), and 35 (Caniquantel plus, Heinz Haupt Pharma GmbH, Germany). Puppies of litter 3 ( $\mathrm{n}=6,2$ males and 4 females) were born and reared in the household of a dog breeder, and reared in a separated kennel room ca $3 \times 3 \mathrm{~m}$, at an ambient temperature of ca $25^{\circ} \mathrm{C}$ during the first three weeks. They were dewormed at the ages of 2 , 4, 6 and 8 weeks (Banminth paste, Pfizer AH, Belgium). All puppies were weighed at weekly intervals.

Urine samples were collected in the morning between 07.00 and $09.00 \mathrm{~h}$. In the neonatal period, urine was voided after a gentle massage of the inguinal region of puppies over a clean plastic tray and collected using a syringe. In older puppies, urine voided after their waking in the morning was immediately collected from the clean concrete floor using a syringe. All samples were then placed in Eppendorf vials and frozen to $-20^{\circ} \mathrm{C}$ within an hour of collection pending analysis. Cortisol in urine was determined using a RIA kit (Immunotech Prague, a Beckman Coulter Company) cat. 1841. Analysis was performed using a direct method without extraction. Creatinine concentration was determined using the diagnostic kit BioVendor ${ }^{\mathrm{L} K r e a t i n i n}$.

For statisical evaluation of the data, Student's $t$-test, paired $t$-test and Kolmogorov-Smirnov test were used.

\section{Results and Discussion}

The mean body mass of puppies increased from $303 \pm 68 \mathrm{~g}$ on the day of birth to 3508 $\pm 42 \mathrm{~g}$ on day 56 , i.e. more than tenfold. This growth rate was similar to data described for laboratory Beagle dogs by Field and Jackson (2006).

We found no significant differences in UCCR (paired $t$-test), when puppies of litters 1 and 2 were compared with those of litter 3 , therefore the data for all puppies were pooled. Thus no effect of the rearing environment upon their UCCR was found in the early postnatal period. The mean UCCR in puppies aged up to 48 hours was $44.3 \pm 30-47 \times 10^{-6}$. However, because the UCCR values found for the individual days did not show a normal distribution (as tested by the Kolmogorov-Smirnov test), only a possible development tendency could be described (see Fig. 1). There was a great individual variability in the UCCR in the period under study. Also plasma creatinine concentration in dogs seems to be subject to great inter-individual variability as found in Beagle dogs (Center et al. 1985; Braun et al. 2003). Kuhl et al. (2000) found higher plasma creatinine in Rottweiler puppies than in Beagle puppies.

In general, the UCCR values in our puppies surpassed substantially those reported for adult and healthy dogs of the same breed. In adult Beagle dogs that have not been exposed to any stress the UCCR of $6.2 \pm 1.0 \times 10^{-6}$ and $11.9 \pm 1.2 \times 10^{-6}$ in dichloromethane extracted and nonextracted urine, respectively, were found (Beerda et al. 1996). Similar basal UCCR, namely, $9.4 \times 10^{-6}$, was reported by Jones et al. (1990), and a median value of $17.8 \times 10^{-6}$ by Stephen and Ledger (2006) for kennelled dogs. Similar median value, namely $10.48 \times 10^{-6}$, was found in ten healthy adult dogs using a RIA method (Kolevská and Svoboda 2000). Median values in our puppies oscillated between $28.29 \times 10^{-6}$ and $71.40 \times 10^{-6}$.

When evaluating the present results, the specifities of the developing kidney have to be 


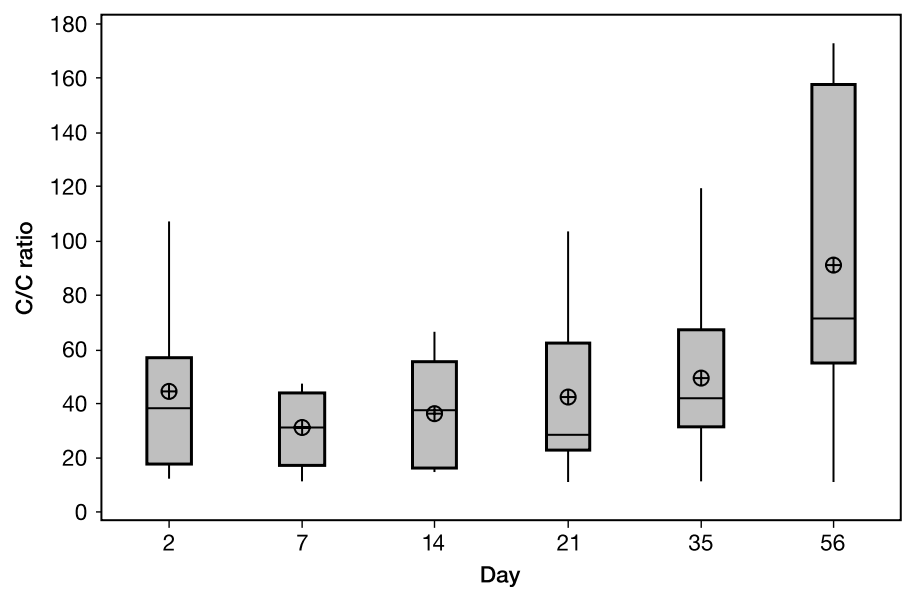

Fig. 1. UCCR of puppies in the early postnatal period (maximum values, quartile $75 \%$, median $=$ horizontal bar, $\oplus=$ arithmetic mean, quartile $25 \%$, minimum values)

taken into consideration. Qualitative urinalysis was performed in young puppies (Faulks and Lane 2003), and the authors stated that it can be interpreted as for adult dogs in puppies older than four weeks. Glucose and protein concentrations approach the values found in adult dogs by 3 weeks of age (Bovee et al. 1984, Fettman and Allen 1991). However, no creatinine concentration was included in these studies. Quantitative studies of blood serum creatinine showed a decrease in the first week of life in Beagle puppies with a stable concentration up to the end of the second month with no differences between males and females (Kuhl et al. 2000). No sex differences in UCCR were found in our puppies. In several studies using other animal species it was shown that the kidney is physiologically programmed to depend on glomerular and tubular actions of prostaglandins in the perinatal and neonatal period (Heymann 1987).

It can be assumed that the widely scattered values of the UCCR in our study were due to morphological and functional immaturity of the canine kidney but may also be connected with changes in creatine and creatinine synthesis in the phase of rapid body and musculature mass increase (the puppies increased their body mass more than tenfold in the period under study). In this context it is important to mention the findings of a significantly higher serum creatinine concentration in healthy greyhound dogs as compared to non-greyhound dogs (Drost et al. 2006). The authors ascribe this difference to the large muscle mass in greyhounds. Furthermore, locomotor activity during the postnatal period affects the activity of creatine kinase as shown in rats (Demin and Androsova 1994) and it may be assumed that it makes itself felt also in the synthesis of creatine and creatinine. No doubt, the profound changes taking place during the first 8 weeks of postnatal life of puppies, from total nutritional and thermoregulatory dependence upon their mother during the neonatal period, when the puppies barely move, to transitional period (days 14-28) with opening of the eyes and ears, beginning of urination and defecation without stimulation by their mother, rapidly increasing locomotor activity (Houpt 1998, Beaver 1999), documented e.g. by a more than twofold and significant $(p<0.01)$ increase in horizontal locomotor activity during a 15-min test (Vostatková 2008) between days 35 and 56 after birth, affect all body systems, including the development of endocrine regulations. It can be speculated that the twofold (though not significant) increase in UCCR between days 49 and 56 may be connected with the above-mentioned changes. 
Matos et al. (1998) observed tubular reabsorption of creatinine in the newborn rabbit, also in premature and term infants (Coulthard 1985). They propose that this is due to a slow urinary flow along the tubule and in particular due to increased back-leak of creatinine along the immature tubular structures. It can be said that tubular reabsorption of creatinine is a physiological phenomenon in the immature developing kidney. Plasma creatinine doubled in the newborn rabbit, the urinary excretion of creatinine must have almost doubled as well due to unchanged slow urinary flow (Matos et al. 1998).

In conclusion, specific postnatal developments of these functions were presumably involved also in our experimental animals. In this study of UCCR in puppies aged 1 to 56 days, values oscillating between $30.52 \pm 3.91 \times 10^{-6}$ and $44.32 \pm 8.80 \times 10^{-6}$ with a non-significant increase to a double value of $91.20 \pm 17.45 \times 10^{-6}$ on day 56 were found, along with considerable inter-individual variability. These values were higher than those reported for adult individuals of the same breed. The specific features of this period should be considered when evaluating the UCCR in puppies.

\section{Postnatální vývoj poměru kortisolu a kreatininu u štěňat}

Cílem studie bylo sledovat věkové změny poměru kortisolu a kreatininu (UCCR) v moči rostoucích štěňat od narození do věku osmi týdnů. Použita byla štěňata plemene bígl (n= 14), ze tří vrhů. Vrhy 1 a 2 byly odchovávány ve výzkumném zařízení, vrh 3 u chovatele. Všechna štěňata byla kojena a od 4. týdne přikrmována. Jednou týdně byla vážena. Ranní moč byla odebírána ve věku do 48 h, a poté $7 ., 14$., 21., 35. a 56. den po narození. Koncentrace kortisolu v moči byla měřena pomocí RIA metody, ke stanovení kreatininu byl použit diagnostický kit. Z výsledků byl vypočítáván poměr kortisolu a kreatininu. Hmotnost štěňat vzrostla $v$ pokusném údobí více než $10 \times$. V poměru kortisolu a kreatininu nebyly mezi vrhy nalezeny rozdíly, proto byly všechny hodnoty sloučeny. Vliv různého prostředí se tedy na UCCR neprojevil. UCCR štěňat do $48 \mathrm{~h}$ po narození byl 44,32 $\pm 30,47 \times 10^{-6}$. Následující změny (pokles na 30,52 $\pm 12,98 \times 10^{-6}$ do 7 . dne a podobné hodnoty do 49 . dne), podobně jako vzestup 56 dne významné nebyly. Charakteristickým znakem UCCR štěňat byly hodnoty přesahující nálezy u dospělých psů a velká individuální variabilita, pravděpodobně reflektující procesy maturace jako jsou rychlý růst živé hmotnosti a kosterní svaloviny, změny výživy, pohybové aktivity a dalších funkcí.

\section{Acknowledgements}

The help with rearing of the experimental animals at the Veterinary Research Institute in Brno is appreciated; the local Ethics Committee approved the procedures. Financial support was provided by the Internal Grant Agency of the University of Veterinary and Pharmaceutical Sciences, Brno No. 34/2006.

\section{References}

BEAVER BV 1999: Canine Behavior: A Guide for Veterinarians. W.B. Saunders, 5Philadelphia, 355 p.

BEERDA B, SCHILDER MBH, JASSEN NSCRM, MOL JA 1996: The use of saliva cortisol, urinary cortisol, and catecholamine measurements for a noninvasive assessment of stress responses in dogs. Horm and Behav 30: $272-279$

BEERDA B, SCHILDER MBH, BERNADINA W, van HOOFF JARAM, de VRIES HW, MOL JA1999a: Chronic stress in dogs subjected to social and spatial restriction. I. Behavioral responses. Physiol Behav 66: 233-242

BEERDA B, SCHILDER MBH, BERNADINA W, van HOOFF JARAM, de VRIES HW, MOL JA 1999b: Chronic stress in dogs subjected to social and spatial restriction. II. Hormonal and immunological responses. Physiol Behav 66: 243-254

BEERDA B, SCHILDER MBH, van HOOFF JARAM, de VRIES HW, MOL JA 2000: Behavioural and hormonal indicators of enduring environmental stress in dogs. Animal Welfare 9: 49-62

BOISSY A, le NEINDRE P 1997: Behavioral, cardiac and cortisol responses to brief peer separation and reunion in cattle. Physiol Behav 61: 693-699

BOVEE KC, FINCO DR, DIBARTOLA SP, OSBORNE CA, POLZIN DJ 1984: Renal disease in a cat. Mod Vet Pract 65: 478 
BRAUN JP, LEFEBVRE HP, WATSON ADJ 2003: Creatinine in the dog: A Review. Vet Clin Pathol 32: 162-179

ČAPEK K, HELLER J 1961: Antidiuretic activity of plasma and posterior pituitary lobe during ontogenesis in the dog. Physiol bohemoslov 10: 522-528

CENTER SA, WILKINSON E, SMITH CA, LEWIS RM 1985: 24-hour urine protein/creatinine ration in dogs with protein-losing nephropaties. J Am Vet Med Assoc 187: 820-824

COULTHARD MG 1985: Creatinine and urea clearances compared to inulin-clearance in preterm and mature babies. Early Human Dev 11: 1985:11-19

DEMIN, VI, ANDROSOVA IM 1994: Ontogenic transformations of energy-metabolism in skeletal muscle under different conditions of animal development. Izvestiya Ak Nauk Ser Biol 4: 677-685

DROST WT, COUTO CG, FISCHETTI AJ, MATTOON JS, IAZBIK C 2006: Comparison of glomerular filtration rate between greyhounds and non-greyhound dogs. J Vet Intern Med 30: 544-546

FAULKS RD, LANE IF 2003: Qualitative urinalyses in puppies 0 to 24 weeks of age. J Am Anim Hosp Assoc 39: $369-378$

FELDMAN EC, MACK RE 1992: Urine cortisol: creatinine ratio as a screening test for hyperadrenocorticism in dogs. J Am Vet Med Assoc 200: 1637-1641

FETTMAN MJ, ALLEN TA 1991: Developmental aspects of fluid and electrolyte metabolism and renal function in neonates. Compend Contin Educ Pract Vet 13: 392-403

FIELD G, JACKSON TA 2006: The Laboratory Canine. CRC, Taylor and Francis, Boca Raton, London, New York, $159 \mathrm{p}$.

FINCO DR 1997: Kidney Function. In: Kaneko JJ, Harvey JW, Bruss ML (Eds): Clinical Biochemistry of Domestic Animals. Fifth edition, Academic Press, San Diego, pp. 441-484

HELLER J, ČAPEK K 1965: Changes in body water compartments and inulin and PAH clearance in the dog during postnatal development. Physiol bohemoslov 14: 433-438

HEYMANN MA 1987: Prostaglandins and leukotrienes in the perinatal-period. Clin Perinatol 14: 857-880

HORSTER M, VALTIN H 1971: Postnatal development of renal function: micropuncture and clearance studies in the dog. J Clin Invest 50:779-795

HOUPT KA 1998: Domestic Animal Behavior for Veterinarians and Animal Scientists. Third Edition, Iowa State University Press, Ames, $495 \mathrm{p}$

JONES CA, REFSAL KR, LIPPERT AC, NACHREINER RF, SCHWACHA MM 1990: Changes in adrenal cortisol secretion as reflected in the urinary cortisol/creatinine ratio in dogs. Domest Anim Endocrinol 7:559-72

KOJIMA K, MAKI S, HIRATA K, HIGUCHI S, AKAZAWA K, TASHIRO A 1995: Relation of emotional behaviors to urine catecholamines and cortisol. Physiol Behav 57: 445-449

KOLEVSKÁ J, SVOBODA M 2000: Immunoreactive cortisol measurement in canine urine and its validity in hyperadrenocorticism diagnosis. Acta Vet Brno 69: 217-223

KUHL S, MISCHKE R, LUND C, GÜNZEL-APELAR 2000: Referenzwerte klinisch-chemischer Blutparameter bei Hundewelpen in den ersten acht Lebenswochen. Dtsch Tierärztl Wschr 107: 438-443

LANE IF, SHAW DH, BURTON SA, DONALD AW 2000: Quantitative urinalysis in healthy Beagle puppies from 9 to 27 weeks of age. Am J Vet Res 61: 577-581

MATOS P, DUARTE-SILVA M, DRUKKER A, GUIGNARD JP 1998: Creatinine reabsorption by the newborn rabbit kidney. Pediatr Res 44: 639-641

RUOTSALO K, TANT MS 2004: Testing for urine cortisol/creatinine ratio in dogs. www.fetchdog.com/learnconnect/dog-resource-library/health/diagnostic-tests (accessed April 10, 2008)

STEPHEN JM, LEDGER RA 2006: A longitudinal evaluation of urinary cortisol in kenneled dogs, Canis familiaris. Physiol Behav 87: 911-916

STOLP R, RIJNBERK A, MEIJER JC, CROUGHS RJM 1983: Urinary corticoids in the diagnosis of canine hyperadrenocorticism. Res Vet Sci 34: 141-144

van VONDEREN IK, KOOISTRA HS, RIJNBERK A 1998: Influence of veterinary care on the urinary corticoid: creatinine ratio in dogs. J Vet Intern Med 12: 431-435

VOSTATKOVÁ K 2008: Behaviorální a fyziologické ukazatele ve vývoji psa. (In Czech) Behavioural and physiological indicators in the development of dogs. PhD Thesis, University of Veterinary and Pharmaceutical Sciences Brno, 102 p. v 